\title{
An Overview on Farmers Suicides in India and Intervention to Curb
}

\author{
K.V. Ashalatha ${ }^{1^{*}}$ and N. Rajeshwari ${ }^{2}$ \\ ${ }^{1}$ Department of Agricultural Statistics, University of Agricultural Sciences, Dharwad-580005, \\ Karnataka, India \\ ${ }^{2}$ Department of Extension and Communication Management, University of Agricultural \\ Sciences, Dharwad-580005, Karnataka, India \\ *Corresponding author
}

\section{A B S T R A C T}

\begin{abstract}
Agriculture is synonymous with the word farming in India. Agriculture being an important sector of Indian economy supports more than fifty percent of the population. A cursory look at the timeline reveals that the contribution of agriculture after independence for initial two decades was $48 \%$ and $60 \%$ of GDP. It declined to $26 \%$ in $2001-2002$. The most tragic part of our country is the report of more suicidal deaths is among the farming community. The changes in the agricultural policy, increased cost of agriculture, the negative impact of globalization, liberalization and privatization on agriculture are some of the factors that are related to increasing suicidal tendency among farmers.

Hence, the present paper throws light on the situation and trend of farmers' suicides over the years. According to the National Crime Records Bureau (NCRB) data, more than 2,16,000 farmers have committed suicide since 1997. A record of 262630 farmers has committed suicide in India over the last 16 years. The reasons for farmers suicide has been attributed to many causes like indebtedness, faulty loans and mental traumas. The same is the case in Karnataka where farmers depend on rainfed farming. It is visible from farmers suicide data available for Karnataka that highest number of farmers suicides occurred in well-developed and resource rich districts like Haveri (125), Mandya (118), Mysuru (113) whereas the drought prone districts exhibited relatively less number of suicides. This might be due to the ability of farmers in dry districts to cope up with agrarian distress and their awareness regarding the alternate choices available during dry spells. Now it is time for the Government to come up with certain interventions to curb the farmers suicide like Emphasis on irrigation along with end to end solution on creation of resources for 'More crop per drop' Krishi Sinchayi Yojana, 'Provision of quality seeds and nutrients according to the soil quality of each farm. Large investments in warehouses and cold chains to prevent Post-harvest losses. Promotion of value addition through food processing. To mitigate the risk, introduction of crop insurance scheme at a lower cost. Promotion of allied activities such as Dairy-Animal husbandry, Poultry, Bee-keeping, Horticulture, and Fisheries. According to theory Durkeim's (1896) the probability of committing suicide is relatively higher with those individuals who are dissatisfied against their expectation. Thus, this was reported as one of the prominent farming related reason for suicide in addition to lack of access to irrigation water. In most of the cases it is the investment that farmer makes and suffer losses so there is a need to design such technologies that need minimum investment.
\end{abstract}

\section{Keywords}

Krishi Sinchayi

Yojana,

Intervention,

Agriculture

\section{Article Info}

Accepted:

20 August 2018

Available Online:

10 September 2018

\section{Introduction}

Agriculture is synonymous with the word farming in India. Agriculture being an important sector of Indian economy supports more than fifty percent of the population. A cursory look at the timeline reveals that the contribution of agriculture after independence 
for initial two decades was $48 \%$ and $60 \%$ of GDP. It declined to $26 \%$ in 2001-2002. In India majority of villagers are engaged in agriculture. Agriculture along with other allied activities like animal husbandry, forestry and fisheries is a dynamic and an important component of our economy that provides livelihood for more than 60 percent of the population. The contribution of agriculture to Indian economy in terms of Gross Domestic Product (GDP) is declining steadily, year by year due to the process of industrialization and the economic growth gathered momentum in different five year plans with the manufacturing and service sectors growing rapidly and agriculture limping along, the percentage share of agriculture in GDP reached a level of 17.8 per cent in 2007-08 (Ruddar and Sundaram, 2010). According to union finance minister the GDP from agriculture, forestry and fishing for the year 2008-09 was 16 percent (Anon, 2010). The share of agriculture and allied sectors in GDP for year 2009-10 was 14.6 per cent and for the year 2010-11 it was 14.2 per cent (Ruddar and Sundaram, 2010). The share of agriculture and allied sectors in GDP for the year 2011-12 was 14.4 per cent and for the year 2013-14 it was 13.9 per cent. Despite a steady decline of its share in GDP, agriculture is still the largest economic sector and plays a significant role in the overall socio-economic development of our country. According to data provided by Department of Economics and Statistics (DES) the food grain production for the year $2017-2018$ is 272 million tonnes which is a good symptom for Indian economy, but the picture is not very rosy for farmers on the other side whose livelihood is agriculture. Farmers are facing distress due to many factors viz., vagaries of nature like flood, drought, erratic rainfall, cyclone, nonavailability of suitable inputs coupled with distressed sales, market slut and inflation. Thus the severe distress among the farmers has lead to dramatic rise in the number of suicides among farmer community. The most tragic part of our country is the report of more suicidal deaths is among the farming community. The changes in the agricultural policy, increased cost of agriculture, the negative impact of globalization, liberalization and privatization on agriculture are some of the factors that are related to increasing suicidal tendency among farmers. Hence, the present paper throws light on the situation and trend of farmers' suicides over the years.

\section{Farmer suicides in India}

Historical records relating to frustration, revolts and high mortality rates among farmers in India, particularly cash crop farmers, date back to the 19th century but the cases of farmers suicide was rare. Ganapathi and Venkoba Rao analyzed suicides in parts of Tamil Nadu in 1966. They recommended that the distribution of agricultural organophosphorus compounds be restricted. Similarly, Nandi et al., in 1979 noted the role of freely available agricultural insecticides in suicides in rural West Bengal and suggested that their availability be regulated. Hegde studied rural suicides in villages of northern Karnataka over 1962 to 1970, and stated the suicide incidence rate to be 5.7 per 100,000 population. Reddy, in 1993, reviewed high rates of farmer suicides in Andhra Pradesh and its relationship to farm size and productivity (Wikipaedia). According to the National Crime Records Bureau (NCRB) data, more than 2,16,000 farmers have committed suicide since 1997. A record of 262630 farmers has committed suicide in India over the last 16 years. The States which come either under dry zone or areas under rainfed agriculture have reported the highest number of suicides The major states are Maharashtra, Andhra Pradesh, Karnataka, Madhya Pradesh and Chhattisgarh follow closely, with two thirds $(68.4 \%)$ of farmer suicides being reported from these states. However, the NCRB figures across 18 
years for which data exists how that at least 2,84,694 Indian farmers have taken their lives since 1995 (i.e., accepting the non-figures of Chhattisgarh and West Bengal). The average annual famers suicides is 15,369 over a period of 18 years. During the period 1997-2002, farmer suicides in the big five states accounted for roughly one out of every twelve of all suicides in the country. In 2003-08, it accounted for nearly one out of every ten. India saw 1,38,321 farm suicides between 1995 and 2003 at an annual average of 15,369. During the period 2004-12, the number is $14,66,373$ at much higher annual average of 16,264. The annual average farmers suicides during 1995-2002 is the highest at 2,508 in Maharashtra followed by Madhya Pradesh and Chhattisgarh (2,304), Karnataka (2,259); while in the case of 2003-10 its place is the same as reported by Ashalata and Das

During last nearly one year, of 9187 people committed who suicide in MP, over $21 \%$ (1982) were from agriculture sector-farmers and farm labourers. This translates into one person committing suicide every hour and one farmer every five hours in the state over last one year. This came to light after data on suicides HT compiled the data submitted in the state assembly this month coupled with the data shared in the House in December and July sessions last year. NCRB data, were attributed to farming related issues, crop failure, inability to sell their agricultural produce, inability to repay loans and other factors like poverty, property disputes, marriage related issues, family problems and illness.

\section{Farmer suicides in Karnataka}

Karnataka is becoming a suicide hub in the recent times. Even at the time of agrarian crisis farmers have resorted to eating alternate foods and seeking alternate employment. The suicide of farmers can be traced with farmers who out rightly cultivate commercial crops. It is visible from farmers suicide data available for Karnataka that highest number of farmers' suicides occurred in well-developed and resource rich districts like Haveri (125), Mandya (118), Mysuru (113) whereas the drought prone districts exhibited relatively less number of suicides. This might be due to the ability of farmers in dry districts to cope up with agrarian distress and their awareness regarding the alternate choices available during dry spells. Such farmers are seen to have evolved over a period of time with various strategies that can successfully help them manage the stress conditions. On a contrary the farmers from resource rich areas are left with fewer options to take up. For instance in command areas, the main crop is usually paddy and during water crisis, they hardly have any other option to sustain the crop since techniques like drip irrigation and mulching are not practical options. Hence creating awareness regarding various other options available for means of survival and imparting training to such farmers on various skills has to be made as reported by Manjunath and Ramappa in 2017.

In Karnataka, the Department of Agriculture recorded four farmer suicides per day between the periods from July, 2015 to June, 2016. Out of 1490 farmer suicides that occurred during this period in Karnataka, 80 per cent were committed by marginal and small farmers. The period of July, 2015 to October, 2015 (Kharif) was peak of farmers frustration in Karnataka as 56 per cent of suicides occurred during this period. The intensity of suicides in Mandya was extremely high at 62 suicides per lakh hectares of net sown area and 49 farmer suicides per lakh hectare of gross sown area. Haveri had the highest of 57 suicide cases per lakh of farming families. An amount of Rs. 39.20 crores was paid as compensation to 784 victim families at the rate of Rs. 5 lakhs per family during period from July 2015 to June 
2016. While 408 cases were rejected, 298 cases were pending for which decision has to be taken.

\section{Objective}

To review the causes for farmers suicide in India and Karnataka and remedial measures to prevent farmers suicide

\section{Materials and Methods}

For evaluating specific objectives of the study, Secondary data on the number of farmer committed suicides were collected from different sources. The reports, newspapers, the respondents or family members of the person who committed suicide were taken for assessment. The present paper is a review article to give a picture of farmers' suicides.

\section{Results and Discussion}

Farmer suicides account for approximately $10 \%$ of all suicides in India. (Times of India (TOI), 2017)

From Table 1 it is evident that from the year $2000-2004$ there is an increasing trend in the number of farmer's suicides. Though the number of suicides decreased during 20052008 it was only in few hundreds and not a steep decline. In the year 2009, 1172 more farmers committed suicide then the year 2008 . But after 2010 it is observed that there is a steady decline in number of suicides; again in 2014 there is increase in farmer's suicide all over India. Again in the year 2016, 242 more farmers took their lives as compared to 2015 where 12360 lost their lives. According to Naik (2018) the list includes farmerscultivators and agricultural labourers. $\mathrm{He}$ further elaborates that seven states account for $87.5 \%$ of total suicides in the farming sector in the country. The states are Maharashtra, Karnataka, Telangana, Madhya Pradesh,
Chhattisgarh, Andhra Pradesh and Tamil Nadu and both marginal farmers and small farmers are committing suicide. Maharashtra is the worst affected state 10,451 farmer have committed suicide from 2001-2014(Kale, 2014). Ironically, Punjab, which benefited most from the Green Revolution, also presents a depressing picture of farmer's suicides in India. Between 1995 and 2015, 4687 farmers' suicides have been reported from the state of Punjab of which 1334 from one Mansa district alone.

A comprehensive analysis of varied sources on the reasons for farmers suicide state that monsoon failure, climate change, high debt burdens, government policies, mental health, personal issues and family problems if it is reviewed deeply increase in input costs like chemicals, seeds, fertilizers, which are to be purchased from outside, water crisis, interstate water disputes, dominance of money lenders and contractors over marketing channels are the most prominent factors responsible for farmers suicide. Further, family labour which was the most cost effective no cost investment earlier is not seen anywhere because of fragmentation of land holdings. Another complicated and indirect issue is India's urban consumer driven economic policies as the farmer has no control over price because of Essential Commodities Act, 1955. Most studies identified indebtedness as the predominant single factor associated with farmer suicides Dongre and Deshmukh (2012) found that farmers in the Vidarbha region of Maharashtra ranked debt as the most important reason for farmer suicides, followed by addictions, environmental problems, and price issues, amongst others Two other studies concluded that unpaid loans are a correlate of those who die by suicide. Kale (2011) found that in a small sample from Vidarbha, 95\% of farmer suicide victims were indebted, while of control households, this was only $25 \%$. 
Another in the same region found that 197 of 200 victims $(98.5 \%)$ were indebted. Mishra (2014) also found that debt was the most common factor in Maharashtra at $86.5 \%$, followed by deterioration in the farmers' economic status $(73.9 \%)$. A comparison of these farmers with those who had not died by suicide showed they had three times as much debt, and the difference was significant to the $95 \%$ confidence interval as reported by Merriott in 2016 in his analytical paper on factors associated with the farmers' suicide crisis in India. An investigation of the socioeconomic causes of farmer suicide in Karnataka also found that agricultural debt was given as the primary factor, leading to farmer suicides in 29/30 suicide cases Nagathan, et al., 2011.

The above data in Table 2 from various sources reveal that during the last seventeen years 34, 188 farmers have committed suicide. Though there is decreasing trend only in 2014 i.e. less than 1000 people committed suicide, again it rose in 2015 and 2016. A research report submitted and published by Manjunatha and Ramappa in 2017 on Farmer Suicides in Karnataka revealed that the highest number of farmers who had committed suicides belong to marginal and small holdings category (80\%) and 45 percent of the victims opined that the income from agriculture has decreased over the last five years and agriculture was no more an attractive occupation. The data also showed that 84 per cent of the victim households were in the age group of 31 to 60 years and 65 per cent had education only up to seven years of formal education because agriculture was the only option for them and they had to embrace agriculture for livelihood. The reasons given by the family members for suicide were varied and expressed some or the other symptoms like restlessness and insomnia. The family members have revealed that several incidents also have triggered suicide like the victim spoke very pessimistically about the success of crop; some lender visited their house; the entire family had to be without food; the son of victim refused to go to school since the fee was not paid; the victim returned without collecting money from the factory to which he had sold his produce and had visited several times; the victim expressed deep concern about the debt burden. Several suicides were told to have happened immediately after such incidences or after couple of days. The social causes were the worry of daughter's marriage as reported by 14 per cent of the sample victims. Marriage related issues like dowry, extra-marital relations, divorce and love failure were not at all the causes for suicide.

Among the several farming related causes mentioned by the family members of victim, irrigation problem was the most important. In 2015-16, this cause was reported by 85 per cent (lack of access to irrigation water plus failure of rainfall/drought) of the victim households. While in 2014-15 this cause was reported by 45 per cent of the victim households. Results also indicated that crop loan was the top most reason for victims to commit suicide. However, a close look at the table reveal that failure of rain, lack of irrigation facilities and attack of pests and diseases together is much bigger cause than crop loan because these were the causes for crop failure.

According to Press Trust of India (2017), 3,515 farmers in Karnataka committed suicide between April 2013 and November 2017, out of which 2,525 were due to drought and farm failure, statistics provided by the State Agriculture Department said. "3,515 farmers were reported to have committed suicide from April 2013 to November 2017, and from April 2008 to April 2012, as many as 1,125 farmers were reported to have committed suicide," it said. Out of the 3,515 suicide cases reported, agriculture department accepted 2,525 cases which were due to drought and crop failure, 
the data said. From April 2015 to April 2017, as many as 2,514 suicide cases were reported, of which 1,929 cases were accepted, it added. From April 2017 to November 2017, when the state received sufficient rainfall, as many as 624 suicide cases were reported. Of these, 416 cases were accepted, it said. Srinivas said. The Sugarcane growers top the list of suicides, followed by cotton and paddy cultivators as per the Department of Agriculture officials. However, the government has taken relief measures asking banks not to force farmers to repay their dues and turn their short and medium-term crop loans into long-term as reported by economic times. He expressed drought and huge crop losses coupled with mounting debts have triggered a fresh spate of farmer suicides in the state during 2017.

\section{Government interventions to prevent farmer's suicide}

2006 relief package - primarily aimed at 31 districts in the four states of Andhra Pradesh, Maharashtra, Karnataka, and Kerala with a high relative incidence of farmers' suicides.

Agricultural debt waiver and debt relief scheme, 2008 - Agricultural Debt Waiver and Debt Relief Scheme in 2008 benefited over 36 million farmers at a cost of 65000 crore rupees This spending was aimed at writing of part of loan principal as well as the interest owed by the farmers.

2013 diversify income sources package - In 2013, the Government of India launched a Special Livestock Sector and Fisheries Package for farmers suicide-prone regions of Andhra Pradesh, Maharashtra, Karnataka and Kerala. The package was aimed to diversify income sources of farmers.

Apart from these Central Government initiatives, there are many efforts from the state governments side like Maharashtra Bill to regulate farmer loan terms, 2008 and Kerala Farmers' Debt Relief Commission (Amendment) Bill, 2012 and Karnataka Government has also agreed for loan waiver of two lakhs.

Policies of integrated pest management to prevent pest damage - An all-inclusive approach that integrates biological, chemical, mechanical and physical methodology should be used to prevent crop damage.

Lower fertilizer costs - Helping fertiliser industries cut down on costs, through internal funding rather than external borrowing should lower the input costs.

Leveraging advancements in Science and Technology by ensuring that state seed policies focus on new genotypes,

Contract farming and sensitization to adverse weather conditions.

The Fasal Bhima Yojana a crop insurence scheme

Paramparagat Krishi Vikas Yojana to encourage traditional and sustainable organic farming.

\section{Strategies for doubling farmers income}

Emphasis on irrigation along with end to end solution on creation of resources for 'More crop per drop' Krishi Sinchayi Yojana

'Provision of quality seeds and nutrients according to the soil quality of each farm.

Large investments in warehouses and cold chains to prevent Post-harvest losses.

Promotion of value addition through food processing. 
States with Most Farmer Suicides (2014)

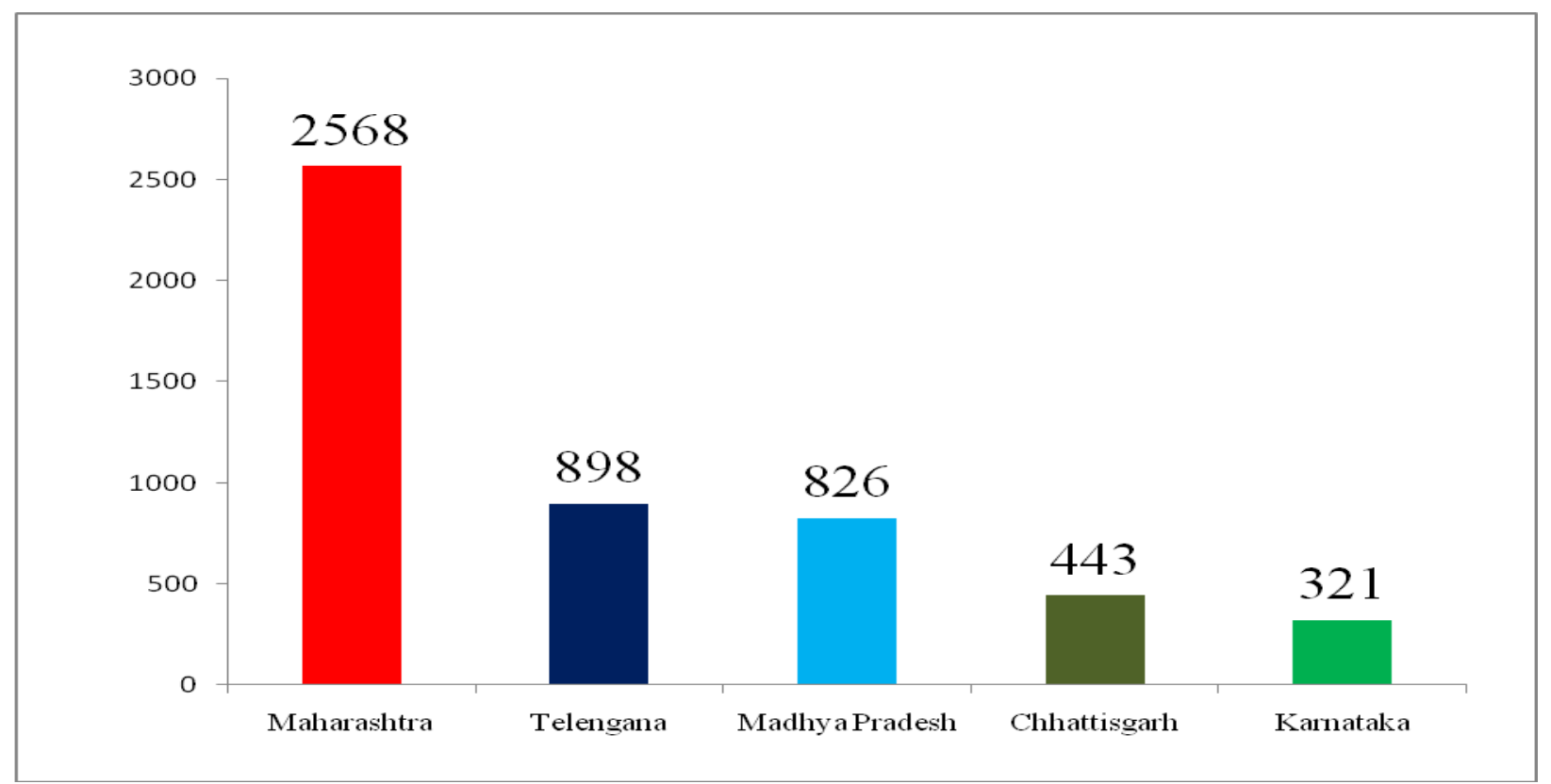

Source: ADSI (Accidental Death and Suicides India), 2014, NCRB

Table.1 Number of Farmers (Farming/Agricultural labourers) committed suicide during 2000 - 2016 in India

\begin{tabular}{|l|l|}
\hline Year & No. of Farmers Committed Suicide \\
\hline 2000 & 16603 \\
\hline 2001 & 16415 \\
\hline 2002 & 17971 \\
\hline 2003 & 17164 \\
\hline 2004 & 18241 \\
\hline 2005 & 17131 \\
\hline 2006 & 17060 \\
\hline 2007 & 16632 \\
\hline 2008 & 16196 \\
\hline 2009 & 17368 \\
\hline 2010 & 15964 \\
\hline 2011 & 14027 \\
\hline 2012 & 13754 \\
\hline 2013 & 11772 \\
\hline 2014 & 12360 \\
\hline 2015 & 12602 \\
\hline 2016 & 11370 \\
\hline Total & $\mathbf{2 6 2 6 3 0}$ \\
\hline
\end{tabular}

Source: Various issues of Accidental Deaths and Suicides in India (ADSI), National Crime Records Bureau (NCRB), Ministry of Home Affairs, Government of India \& www. indiastat.com 
Table.2 Number of Farmers (Farming/Agricultural labourers) committed suicide during 2000- 2016 in Karnataka

\begin{tabular}{|l|l|}
\hline Year & No. of Farmers Committed Suicide \\
\hline 2000 & 2630 \\
\hline 2001 & 2510 \\
\hline 2002 & 2340 \\
\hline 2003 & 2680 \\
\hline 2004 & 1960 \\
\hline 2005 & 1880 \\
\hline 2006 & 1720 \\
\hline 2007 & 2140 \\
\hline 2008 & 1740 \\
\hline 2009 & 2280 \\
\hline 2010 & 2590 \\
\hline 2011 & 2100 \\
\hline 2012 & 1800 \\
\hline 2013 & 1400 \\
\hline 2014 & 770 \\
\hline 2015 & 1569 \\
\hline 2016 & 2079 \\
\hline Total & 34188 \\
\hline
\end{tabular}

(Manjunatha and Ramappa, 2017)

Implementation of National Agricultural Markets and e-platforms (e-NAM) to eliminate shortcomings of all the 585 centers.

To mitigate the risk, introduction of crop insurance scheme at a lower cost.

Promotion of allied activities such as DairyAnimal husbandry, Poultry, Bee-keeping, Horticulture, and Fisheries.

Role of various stakeholders in mitigating farmers' suicides

\section{Government}

Marginal and small farmers who cannot sustain due to small holdings should be encouraged to take up alternative enterprises. In drought affected areas the government could start employment generation programmes on the same lines of MNAREGA to reduce the dependency on agriculture as the sole source of income

Provision of relief facilities alone is not sufficient as it has been observed in the case of various states where farmers committed suicides just to avail the benefits of relief packages.

Relief packages should be given as a benefit to farmers to enable them to sustain their livelihood rather than as a relief to families of farmers who commit suicide

\section{Agricultural universities and line departments}

Contingent crop planning with the help of precision farming ie planning based on the precipitation. 
By using some suitable ways and delivering successful stories to farmers they can minimize the expenditure and maximize the income

Vertical Farming can be encouraged and Hydroponics can be taken as small trials by exploring local markets

Corporate Social Responsibility (CSR) must be encouraged in the agricultural sector, particularly towards capacity-building, skill development and the establishment of CHCs.

Institutional financing must also be ensured to be adequate and inclusive rather than catering to the elites within the farming community.

Cooperative farming must be promoted amongst small and marginal farmers and contiguous farming should be encouraged

Early-warning signals for unsustainable loans to launch a 2-pronged approach catering to both the burdened farmers as well as stressed banks.

Insurance claim settlements must be speedy and just.

District wise list of indebted farmers and efforts in de-stressing them through counselling and other alternative mechanisms should be tried.

NABARD and local administration must take control of the situation and play a greater role in curbing farmers' suicides.

The urban population which is dependent on rural economy for food should try to adopt villages

Efforts like Agro-Climatic zoning, education through DD Kisan, Soil Health Card Scheme, various crop insurance and facilitative schemes like PM Krishi Sinchayi Yojana will go a long way in helping out

Community-led awareness must be taken employing a role model approach highlighting progress of farmers who have benefited from sustainable and climate-tailored agricultural practices

\section{Financial institutions}

Bank and other financial sector should not exploit the farmers.

Farmers should not be harassed or disgraced for non-repayment of loan.

Making institutional finance available to every farmer is another important solution to save to the farmers from debt traps of money lenders. Where institutional finance is available, it should be made easily accessible to the poorest farmers. This calls for removing of elaborate formalities and procedures for obtaining the loans.

A poor farmer would be unable to understand the complexities of procedures, he needs a simple solution for his financial needs. Effective monitoring of the disbursed funds is also required because in many cases, the poor farmer is used as a front-end while in fact the benefit of the loan is availed by a bigger land owner. In addition, monitoring is also needed to ensure that the farmers are using the funds for the right purposes

\section{Media}

Reduction in negative publicity through visual medias and also reducing the publicity by not publishing on the front page of news paper

Media should not always blame the Government and create awareness that committing suicide is a crime. 
The family members' dependent on the person who commits suicide will not get any life insurance.

Success stories of farmers who have overcome depression and started a new life should act as motivators to farmers who are under loss

According to theory Durkeim's (1896) the probability of committing suicide is relatively higher with those individuals who are dissatisfied against their expectation. Thus, this was reported as one of the prominent farming related reason for suicide in addition to lack of access to irrigation water. In most of the cases it is the investment that farmer makes and suffer losses so there is a need to design such technologies that need minimum investment.

\section{References}

Ashalatha K.V and Das, C 2016, An Overview on Farmers Suicidal Tendency In India, The ResearcherInternational Journal of Management Humanities and Social Sciences 1(1): 19-32

Dongre, A. R. And Deshmukh, P.R., 2012 Farmers Suicides in the Vidarbha region of Maharasgtra, India: a qualitative exploration of their causes, J. Inj. Violence Res., 4:2-6

https/www.clearias.com/farmers-suicides https://economictimes.indiatimes.com/news/p olitics-and-nation/3515-karnatakafarmers-committed-suicide-in-fiveyears/articleshow/62264877

https://thewire.in/wpcontent/uploads/2017/04/Annex-1

Manjunatha, A.V and K.B, Ramappa 2017, Farmer Suicides in Karnataka, Agriculture Development and Rural Transformation Centre Report, Institute for Social and Economic Change, Karnataka

Merriott, D., 2016, Factors Associated with Farmers Suicide: Crisis in India, Journal of Epidemiology and Global Health, 6(4): 2017-227

Nagthan, S., R. Poddar, L.B. Kunnal, H. Basvaraja, B. Banakar, 2011, A probe into socio-economic and psychological profile of farmers' suicide in Karnataka, Karnataka J Agric Sc iences, 24 (1) pp. 157-160

www. indiastat.com

www/economictimes.indiatimes.com/articlesh ow/62264877

\section{How to cite this article:}

Ashalatha K. V. and Rajeshwari N. 2018. An Overview on Farmers Suicides in India and Intervention to Curb. Int.J.Curr.Microbiol.App.Sci. 7(09): 3032-3040.

doi: https://doi.org/10.20546/ijcmas.2018.709.xx 